\title{
Production and Evaluation of Table Wine Using Two Different Varieties of Pawpaw (Carica papaya)
}

\author{
David Barine Kiin-Kabari, Queen Igbo and Lucretia Ifeoma Barber \\ Department of Food Science and Technology, Rivers State University, Nkpolu Oroworukwo PMB 5080, Port Harcourt, Rivers State, \\ Nigeria
}

\begin{abstract}
The aim of this study was to produce and evaluate table wine from two different varieties of pawpaw (rose red and yellow pawpaw). The must was evaluated for physicochemical and microbiological changes during fermentation while the wine was analyzed for physicochemical characteristics, microbiological quality and sensory properties and compared with commercial grape wine. Specific gravity of the "must" during fermentation decreased from 1.059-0.995 for rose red pawpaw and 1.005-0.990 for yellow pawpaw. The sugar content decreased from $13-3 \%$ on the 14th day of fermentation for rose red pawpaw while yellow pawpaw "must" decreased from 12.5-3\%. pH drop for the yellow pawpaw "must" was 4.7-3.4 on the 14th day and 4.0-3.4 for rose red pawpaw "must". Titratable acidity of the pawpaw "must" increased from $0.16-0.32 \%$ for rose red pawpaw "must" and $0.20-0.52 \%$ for yellow pawpaw "must". Microbial analysis of the "must" during fermentation showed that yeast count increased from no growth to $3.0 \times 10^{6} \mathrm{cfu} / \mathrm{mL}$ for yellow pawpaw must and $4.0 \times 10^{6} \mathrm{cfu} / \mathrm{mL}$ for rose red pawpaw, respectively while total bacterial count decreased from $5.4 \times 10^{7}-1.5 \times 10^{7} \mathrm{cfu} / \mathrm{mL}$ for yellow pawpaw must and $5.2 \times 10^{7}-1.2 \times 10^{7} \mathrm{cfu} / \mathrm{mL}$ for rose red pawpaw "must". Coliform recorded no growth throughout the period of fermentation. Physicochemical analysis of the wine showed that the yellow pawpaw wine has a specific gravity of 0.999 , alcohol content $8.00 \%$, titratable acidity of $0.59 \%$, pH of 3.5 and sugar content of $3 \%$. The rose red pawpaw wine had sugar content of $3 \%$, titratable acidity of $0.38 \%$, alcohol content $7.69 \%$, specific gravity 0.997 and $\mathrm{pH}$ of 3.5. Microbial analysis of the wine showed no growth of coliform and yeast while bacterial count was $1.0 \times 10^{6} \mathrm{cfu} / \mathrm{mL}$ for both wines. Sensory results for the pawpaw wine showed no significant $(p>0.05)$ difference in the clarity and overall acceptability from the commercial wine.
\end{abstract}

Key words: Red rose, yellow pawpaw, table wine.

\section{Introduction}

Wine, an alcoholic beverage is produced from the fermentation of fruit juices especially grape which have a chemical balance that allows them to ferment without addition of sugar, acids, enzymes or other nutrients [1]. Many tropical and subtropical fruits, including grapes, apples, pears, apricots, berries, peaches, sugar cane, oranges, mangoes, bananas and pineapples yield good amounts of juice on extraction $[1,2]$. Upon fermentation, fruit juices can be changed into wines [3-6]. Different varieties of grapes and strains of yeasts produce different styles of wine. These variations result from the complex interactions

Corresponding author: Kiin-Kabari, D. B., Ph.D., reader, research fields: food science and technology. between the biochemical components of the grape, the reactions involved in fermentation and the overall production process [7].

Wines are classified as natural wines having an alcoholic content of $9-14 \%$ and dessert and appetizer wines with alcohol content $15-21 \%$. Wine can also be categorized as sweet or dry depending on the conditions during alcoholic fermentation. The subjective sweetness of a wine is determined by the interaction of several factors, including the amount of sugar in the wine, but also the relative levels of alcohol, acids and tannins [8]. In general, sugars and alcohol enhance a wine's sweetness while acids and tannins counteract it leading to a dry wine [9]. The most famous types of wines are red and white wines, followed by rosé and sparkling wines. Table wines are 
dry if sugar content is $0.3 \%$ and alcohol $9-14 \%$, semi-dry with sugar content of $0.5-3 \%$ and alcohol $12.9 \%$ and sweet with sugar $3-8 \%$ and alcohol $12.9 \%$ [10].

Pawpaw (Carica papaya) is cultivated throughout the tropical and subtropical regions of the world. Botanically, pawpaw plant belongs to the Caricaceae family of flowering plant, in the genus Carica. It is a berry fruit developed from syncarpous ovary with parental plancentation $[11,12]$. Pawpaw is largely cultivated in Nigeria and its fruit is widely consumed raw as dessert, and also processed into different products like jam, jelly and marmalades. Its green peels are boiled and consumed for medicinal purposes and the seeds possess significant antioxidant activities [13-15]. Papaya varies in sizes, shape, color and taste. In Malaysia, the preference is for the red-fleshed varieties namely Eksotika [16]. The skin color of papaya is usually green when immature, changing to fully reddish-orange when fully ripened. The changed in outer color of the skin of fruit is an indicator of ripeness, and this change is considered mainly due to an increase in the carotene content and a decrease in chlorophyll. The color of papaya fruit flesh is determined largely by the presence of carotenoid pigments. Red-fleshed papaya fruit contains lycopene, whilst this pigment is absent from yellow-fleshed fruit [17]. The red-fleshed papaya has $63.5 \%$ of total carotenoids as lycopene which is absent in yellow-fleshed fruit. Zaman et al. [18] studied the physicochemical composition of four papaya varieties and these varieties differed in respect to their physical and chemical characteristics. Fruit weight of the different papaya varieties varied from 645.40 to $1,740.00 \mathrm{~g}$. The highest fruit weight was recorded in Bombai and the lowest in Shahi (red variety). It was also found that recovery of pulp, total soluble solid and total sugar were $80.46-87.41 \%, 9.0-13.0 \%$ and 6.96-10.50\%, respectively [18]. Although numerous studies exist on table wine production, there is paucity of information on the physicochemical characteristics and microbiological quality of table wine produced from pawpaw (Carica papaya). Thus, the objective of this study was to produce table wine from two varieties of Carica papaya (red rose and yellow pawpaw), and evaluate their physicochemical characteristics, microbiological quality and overall acceptability.

\section{Material and Methods}

\subsection{Material}

Red rose and yellow pawpaw varieties used for this study were purchased from Mile 3 Market Diobu, Port Harcourt, Rivers State, Nigeria.

\subsection{Method}

\subsubsection{Processing of the "Must"}

The method of Okoro [19] was used in the preparation of the "must" during the study. The pawpaw fruits were collected in a clean sterile basin, washed with water containing sodium metabisulphate $(0.3 \mathrm{~g} / \mathrm{L})$, peeled, removed seeds and pulverized using sterile Philip electric blender with the addition of water. The slurry was further diluted in a ratio of $1: 1$ (water and pulp) and sieved with a muslin cloth of pore size $0.8 \mathrm{~mm}$ to obtain the filtrate "must" as shown in Fig. 1.

2.2.2 Chaptalization and Supplementation of the "Must"

The methods of Amerine and Kunkee [20] as used by Robinson [21] were used. Eight litres of the must was poured into a white plastic vessel (bucket). The must was chaptalized with $800 \mathrm{~g}(10 \mathrm{~g} / \mathrm{L})$ of sugar and dissolved in some quantity of "must". The must was enriched with $6.72 \mathrm{~g}(0.84 \mathrm{~g} / \mathrm{L})$ of ammonium sulphate and $9.6 \mathrm{~g}(1.2 \mathrm{~g} / \mathrm{L})$ of potassium dihydrogen phosphate to enhance the rapid growth of the fermenting yeast.

\subsubsection{Primary Fermentation}

A broth culture $(200 \mathrm{~mL})$ containing $2.0 \times 10^{8}$ $\mathrm{cfu} / \mathrm{mL}$ was pitched into the must in a fermentation 


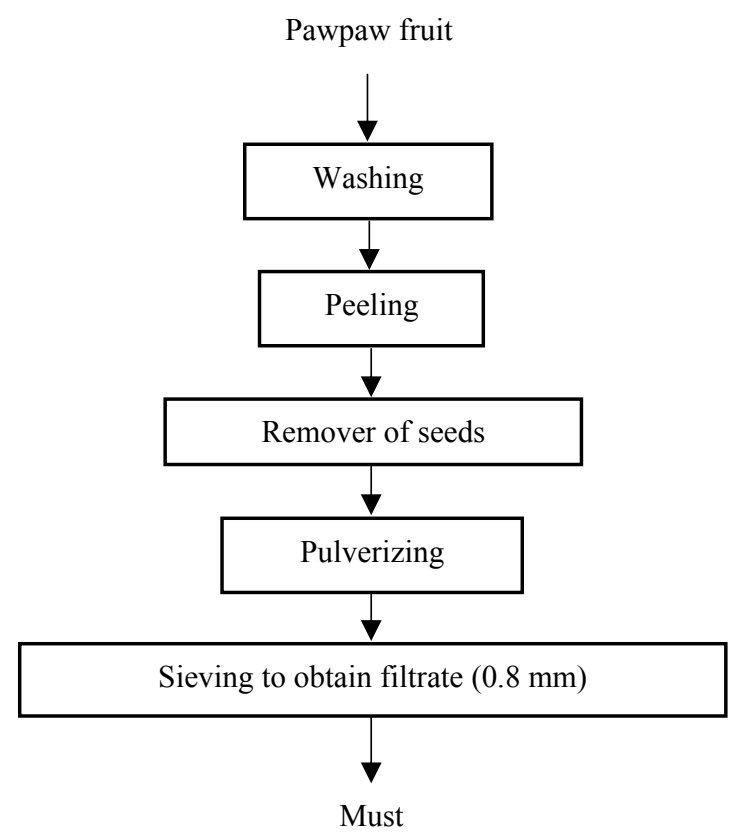

Fig. 1 Flow process diagram for the production of must from pawpaw fruit.

Source: Ref. [19].

vessel by sprinkling it over the surface of the juice. The inoculated must was covered with cotton wool and incubated at room temperature. The fermenting "must" was aerated daily by shaking to encourage yeast multiplication. Aerobic fermentation was terminated after 7 days. During this period, microbial analysis, sugar content, specific gravity, titratable acidity and $\mathrm{pH}$ were monitored at two-day intervals.

\subsubsection{Secondary Fermentation}

After the primary fermentation, an air tap was fixed to the fermenting vessel to indicate the end of primary fermentation. Secondary fermentation was terminated after 7 days and then the wine was filtered. Microbial analysis, alcohol, sugar content, specific gravity, titratable acidity and $\mathrm{pH}$ of the wine were also monitored at the end of the secondary fermentation.

\subsubsection{Clarification and Racking}

After secondary fermentation, the wine was racked weekly for 3 weeks to clear the wine.

\subsubsection{Aging}

After the racking, the wine was kept in the refrigerator for maturation (2 weeks) and then packaged for further analysis as shown in Fig. 2.

\subsection{Physicochemical Analysis of the Wine}

Titratable acidity, total sugar, specific gravity and $\mathrm{pH}$ value were determined using AOAC [22] standard methods.

\subsubsection{Alcohol Content}

The alcohol content of the wine was determined using specific gravity as described by Ogu and Mgbebu [23] and calculated as follows:

Percentage alcohol $=(\mathrm{OG}-\mathrm{FG}) 1.05 \times 100 / 0.8$ where:

$\mathrm{OG}=$ original gravity of the sample;

$\mathrm{FG}$ = final gravity of the sample;

$1.05=$ grams of ethanol per gram of $\mathrm{CO}_{2}$ released;

$0.8=$ density of ethanol.

\subsection{Sensory Evaluation}

The sensory evaluation of the wine was carried out by a 20 semi-trained panelists selected from students and staff of the Department of Food Science and Technology, Rivers State University, Port Harcourt. Samples were scored for taste, aroma, colour, clarity and overall acceptability was calculated. A 9-point 


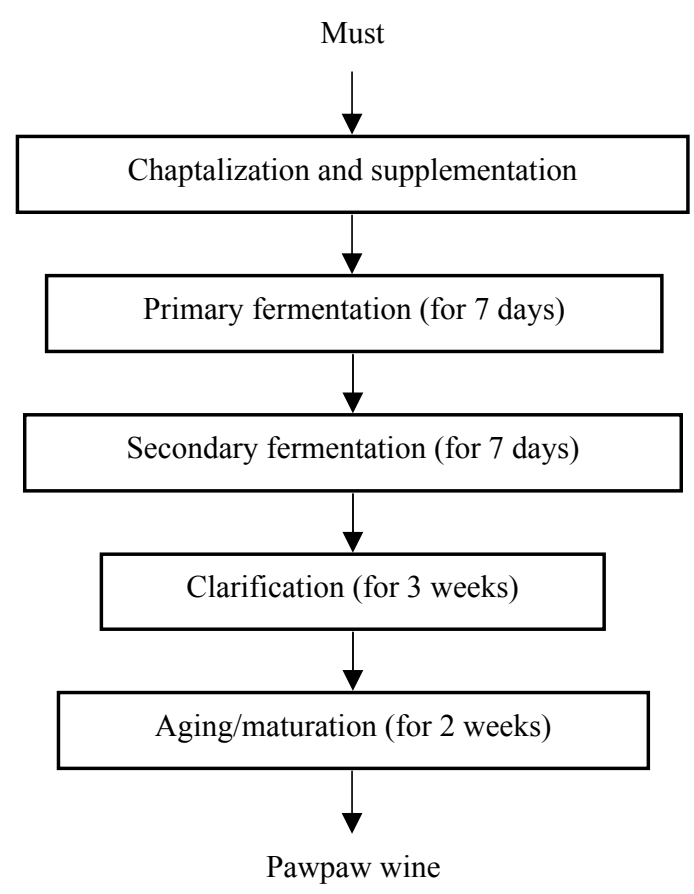

Fig. 2 Flow process diagram for the production of pawpaw wine.

Source: Ref. [21].

hedonic scale as reported by Iwe [24] was used. Commercial wine was used as control.

\subsection{Microbiological Analysis}

\subsubsection{Total Heterotrophic Count (THC)}

The microbiological analysis was carried out according to Harrigan [25]. Plate count agar was used for enumeration of bacteria. A well homogenized sample was serially diluted with $0.1 \%$ peptone water up to $10^{-6}$. One milliliter aliquot from a suitable dilution was transferred aseptically into sterile petri dishes. To each plate about $15 \mathrm{~mL}$ of melted and cooled nutrient agar was added. The inoculated was evenly mixed with media by rotating the plates and allowed to solidify. The inverted plate was incubated for 48 hours. The THC (cfu/mL) was determined using a colony counter.

\subsubsection{Yeast and Mould Enumeration}

Potato dextrose agar (PDA) was used for enumeration of yeast and mould. Well homogenized samples were serially diluted with $0.1 \%$ pepetone water up to $10^{-6}$. Aliquots $(0.1 \mathrm{~mL})$ from a suitable dilution were transferred aseptically into solidified PDA plates. Samples were spread all over the surface of the plates using sterile bent glass rod. The plates were then incubated for $72 \mathrm{~h}$ at $28{ }^{\circ} \mathrm{C}$. Counting $(\mathrm{cfu} / \mathrm{mL})$ was carried out by using colony counter [25].

\subsubsection{Total Coliform Test}

The total coliform test was carried out by multiple tube techniques according to Cheesbrough [26]. One (1 g) of wine sample was diluted in $9 \mathrm{~mL}$ distilled water. A serial dilution was then prepared up to $10^{-3}$. The sample was cultured in MacConkey agar and incubated at $37^{\circ} \mathrm{C}$ for $48 \mathrm{~h}$.

\subsection{Statistical Analysis}

All the analyses were carried out in duplicate. Data obtained were subjected to analysis of variance (ANOVA); differences between means were evaluated using least significant difference (LSD) and significance accepted at $p \leq 0.05$ level of probability. The statistical package for social science (SPSS) V20.0 was used. 


\section{Results and Discussion}

\subsection{Changes in the Specific Gravity of Paw-Paw Must during Fermentation}

Changes in the specific gravity of the fermenting pawpaw must during fermentation are shown in Fig. 3. Specific gravity of the "must" gradually decreased throughout the period of fermentation. From 1 to 14 days of the fermentation, specific gravity values were observed to range from 1.059-0.995 for rose red paw-paw must and 1.005-0.990 for yellow paw-paw must.

\subsection{Changes in the Sugar Content of Paw-Paw Must} during Fermentation

Sugar content of the "must" during fermentation decreased significantly as shown in Fig.4. Yellow pawpaw "must" recorded $13 \%$ on the first day and this decreased to $3.0 \%$ on the 14 th day while rose red pawpaw wine recorded sugar content of $12.5 \%$ and this decreased to $3.0 \%$ on the 14 th day. Decrease in sugar content during fermentation could be due to microbial succession, available nutrients, sugar and alcohol resulting in the production of acid. This result agreed with the reports of Akingbala et al. [4] who observed a decrease in the sugar content of overripe mango wine.

\subsection{Changes in the pH Titratable Acidity of Paw-Paw} Must during Fermentation

Changes in the $\mathrm{pH}$ of the fermenting pawpaw must during fermentation are shown in Fig. 5. Throughout the period of fermentation, $\mathrm{pH}$ of the must was within the acidic range. $\mathrm{pH}$ was 4.7 on the first day and decreased to 3.4 on the 14 th day of fermentation for yellow paw-paw must. For rosered paw-paw must, $\mathrm{pH}$ was 4.0 at first day of fermentation and decreased to 3.4 on the 14 th day of fermentation. Low $\mathrm{pH}$ and high acidity are known to give fermentation yeast comparative advantage in natural environments. A similar observation has been reported by Okeke et al. [27] in their study on mixed fruits (pineapple and

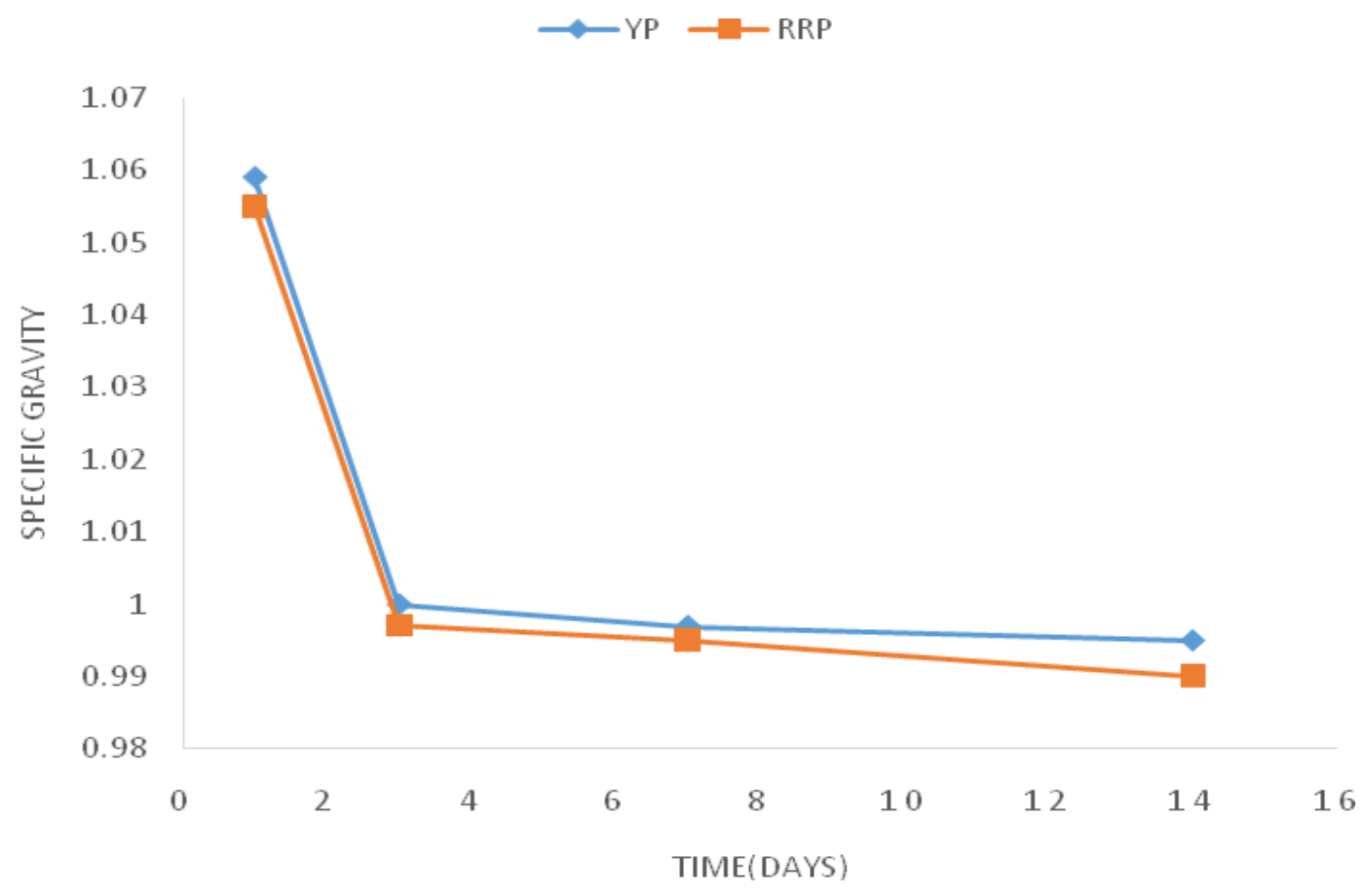

Fig. 3 Variations in the specific gravity of the must during fermentation process. Keys: YP = yellow paw-paw must, RRP = rose red paw-paw must. 


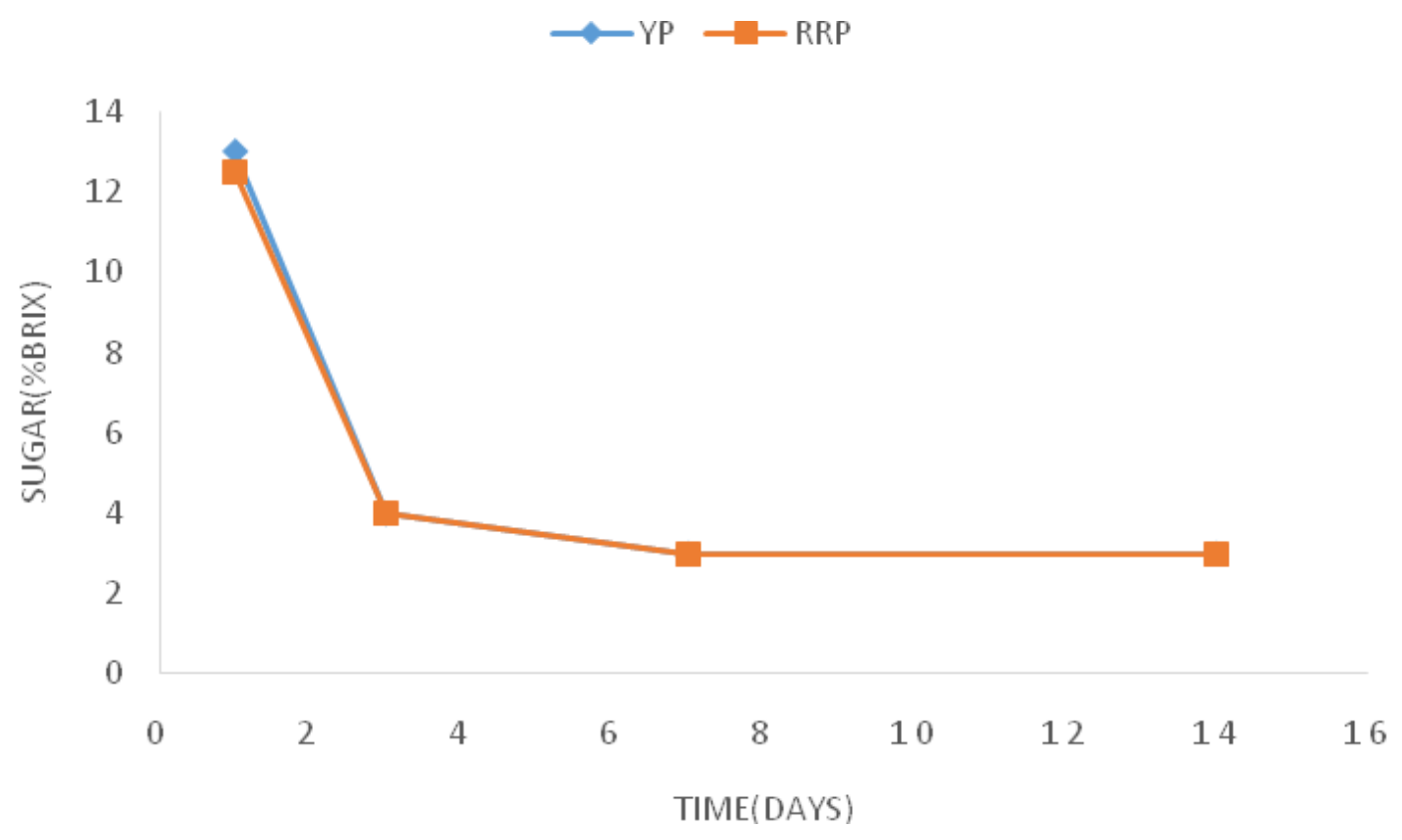

Fig. 4 Variations in the sugar content of the must during fermentation process.

Keys: YP = yellow paw-paw must, RRP = rose red paw-paw must.

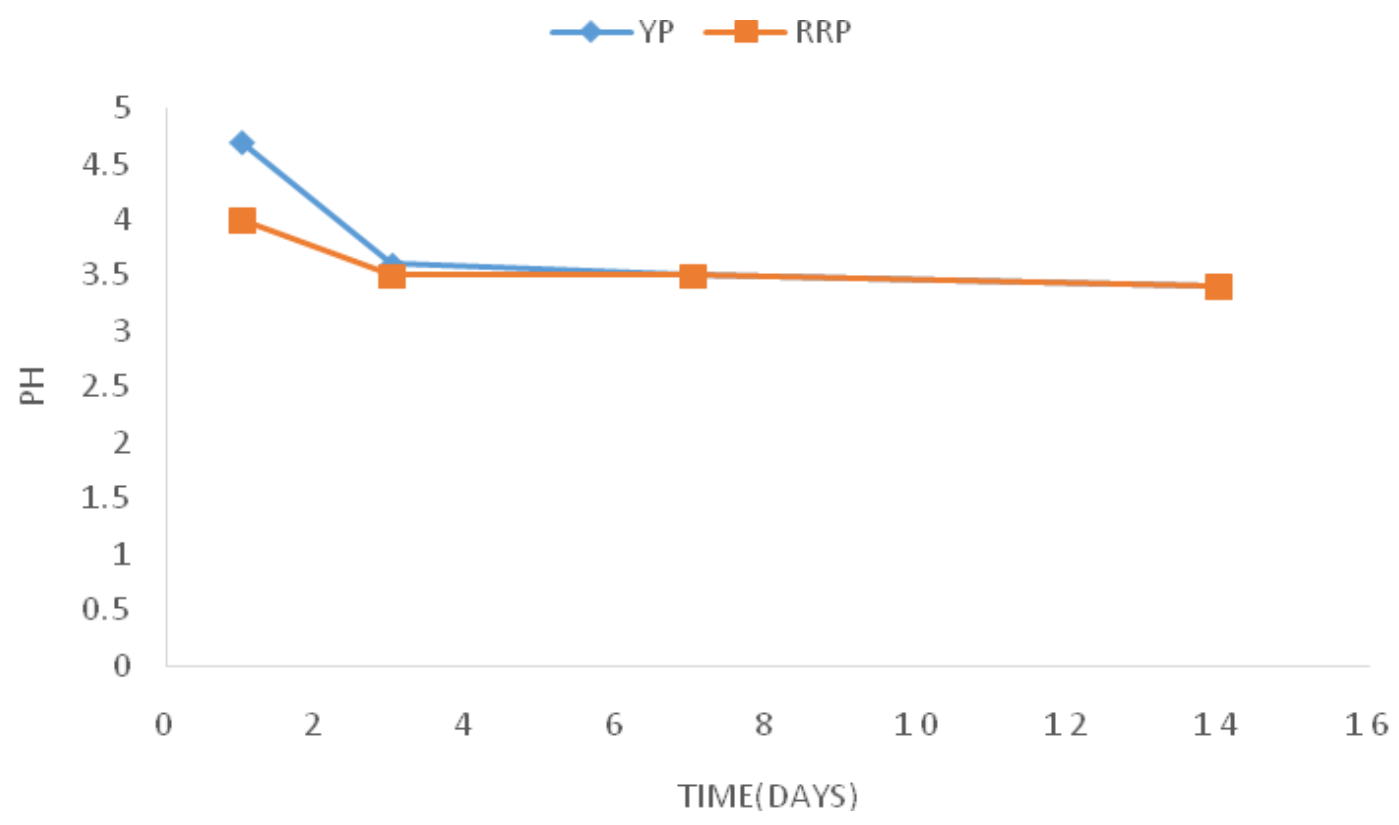

Fig. 5 Variations in the $\mathrm{pH}$ of the must during fermentation process.

Keys: $Y P=$ yellow paw-paw must, $R R P=$ rose red paw-paw must.

watermelon). Ogodo et al. [28] also reported decrease in $\mathrm{pH}$ and an increase in acidity during production of mixed fruit wines of pawpaw, banana and watermelon. The present report is also consistent with the report of other research for some tropical fruit wines such as banana [29], tendu [30] and sweet potato [31]. The decrease in $\mathrm{pH}$ and an increase in acidity could be attributed to production and accumulation of organic 
acids during fermentation. Moreover, low $\mathrm{pH}$ values in wine have been reported to inhibit spoilage bacteria and create favourable environment for the growth of desired organisms [1]. Therefore, the wine from these varieties of pawpaw will have good keeping quality because of their low $\mathrm{pH}$.

\subsection{Changes in the Titratable Acidity of Paw-Paw} Must during Fermentation

As shown in Fig. 6, the acidity of the pawpaw "must" was found to increase throughout the fermentation period from $0.20-0.52 \%$ for yellow pawpaw wine and $0.16-0.32 \%$ for rose red pawpaw wine while the final wine had total acidity of $0.38 \%$, $0.59 \%$ and $0.70 \%$ for rose red, yellow pawpaw wine and the imported wine, respectively. The titrable acidity of the wine is expected to be between 0.5 and
$1.0 \%$ [27]. In this study, the results of titrable acidity of the wines fell within this limit. The acidity was found to be more in yellow pawpaw wine than red pawpaw owing to the chemical composition of these fruit varieties.

\subsection{Physicochemical Properties of the Final (Pawpaw)} Wines

Table 1 showed the physicochemical composition of yellow and red pawpaw wine. Alcohol content for the wines was $7.69 \%, 8.00 \%$ and $7.5 \%$ for rose red, yellow pawpaw wine and the imported wine respectively. The percentage alcohol produced from the fruits used for the fermentation by the yeast strain was above $2 \%$ which is comparable with moderate grape wines $[32,33]$. High alcohols are known to be important precursors for the formation of esters, which

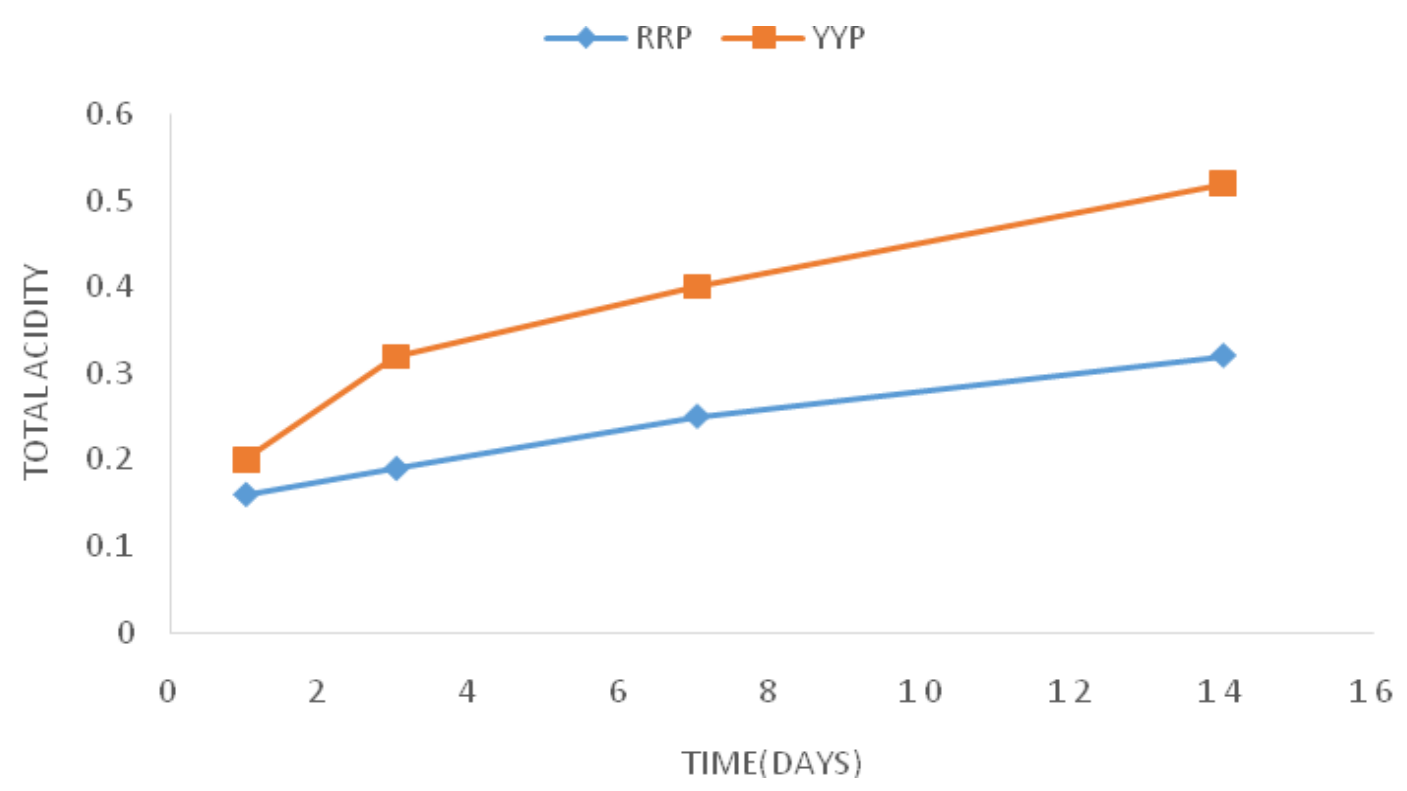

Fig. 6 Changes in the titratable acidity of the must during fermentation process.

Keys: YP = yellow paw-paw must, RRP = rose red paw-paw must.

Table 1 Physicochemical composition of yellow and rose red pawpaw wine.

\begin{tabular}{llll}
\hline Parameter & Rose red pawpaw wine & Yellow pawpaw wine & Imported Reroux grape wine \\
\hline Sugar $\left({ }^{\circ} \mathrm{Bx}\right)$ & 3 & 3 & 9 \\
$\mathrm{pH}$ & 3.6 & 3.5 & 3.0 \\
Specific gravity & 0.997 & 0.999 & 1.021 \\
Alcohol content $(\% v / v)$ & 7.69 & 8.00 & 7.5 \\
TTA $(\%)$ & 0.38 & 0.59 & 0.70 \\
\hline
\end{tabular}


are associated with pleasant aromas [34]. The alcohol content was more in yellow pawpaw wine than in red pawpaw wine also owing to their physiological and chemical composition of these fruit varieties. Reddy et al. [35] reported that the concentration of ethanol contributes to the whole characteristics quality and flavour of produced wine. Hence wine yellow pawpaw wine could be preferred to red pawpaw wine. The final alcohol content of the yellow pawpaw wine which is $8.0 \%$ ranks the yellow pawpaw wine among good table wines. According to Michael [36] a good table wine must have alcohol content between 8 and $14 \%$. The specific gravity of the wine decreased from 1.059-0.995 for the rose red pawpaw wine and 1.005-0.990 for the yellow pawpaw wine while that of the final wine was $0.997,0.999$ and 1.021 for rose red, yellow pawpaw wine and the imported wine, respectively. The final specific gravity of the pawpaw wines obtained falls within the 1.000 and 0.990 sp.gr. range for wine [37]. During fermentation, the changes in specific gravity and reducing sugar $\left({ }^{\circ} \mathrm{Bx}\right)$ of the two varieties of pawpaw wine decreased from the initial day to the end of the fermentation. For the rose red pawpaw must, sugar decreased from 13.0\%-3.0\% while that of the yellow pawpaw must decreased from $12.5 \%-3.0 \%$. Sugar content of the final pawpaw wine was 3\% for both rose red and yellow pawpaw wine while the imported wine had sugar content of $9 \%$.
Inadequate sugar content and low level of acidity have been reported as the major problems associated with making non-grape wine [28]. Upon completion of fermentation, the wine recorded total sugar content of $3 \%$. Since the total sugar content of pawpaw wine is not more than $9 \%$, it implies that it is a dry table wine [10].

It is evident that the differences in the physico-chemical parameters of papaya wine varieties differed from one another which are supposed to be due to different genetic makeup of these varieties and also because of the difference in their total fruit development and ripening period [38].

\subsection{Microbiological Quality of the "Must" and Final (Pawpaw) Wines}

Tables 2 and 3 showed the microbiological quality of the must during fermentation and that of the final (rose red and yellow pawpaw) wine, respectively. Total yeast count of the must recorded no growth on the first day of fermentation and this increased to 3.0 $\times 10^{6} \mathrm{cfu} / \mathrm{mL}$ for yellow pawpaw must and $4.0 \times 10^{6}$ $\mathrm{cfu} / \mathrm{mL}$ for rose red pawpaw must. For total bacterial count, the growth was on a decrease from $5.4 \times$ $10^{7}-1.5 \times 10^{7} \mathrm{cfu} / \mathrm{mL}$ for yellow pawpaw must and 5.2 $\times 10^{7}-1.2 \times 10^{7} \mathrm{cfu} / \mathrm{mL}$ for rose red pawpaw must. For the final pawpaw wines, there was no fungi growth and coliform growth recorded while bacterial count was

Table 2 Microbiological quality of the must during fermentation.

\begin{tabular}{lllll}
\hline Days & Samples & Total bacterial count $(\mathrm{cfu} / \mathrm{mL})$ & Total coliform count $(\mathrm{cfu} / \mathrm{mL})$ & Total yeast count $(\mathrm{cfu} / \mathrm{mL})$ \\
\hline \multirow{2}{*}{1} & YP & $5.4 \times 10^{7}$ & Nil & Nil \\
& RRP & $5.2 \times 10^{7}$ & Nil & Nil \\
3 & YP & $2.5 \times 10^{7}$ & Nil & $3.0 \times 10^{6}$ \\
& RRP & $2.3 \times 10^{7}$ & Nil & $3.0 \times 10^{6}$ \\
7 & YP & $1.5 \times 10^{7}$ & Nil & $3.0 \times 10^{6}$ \\
& RRP & $1.2 \times 10^{7}$ & Nil & $4.0 \times 10^{6}$ \\
\hline
\end{tabular}

Keys: $\mathrm{YP}=$ yellow paw-paw wine, $\mathrm{RRP}=$ rose red paw-paw wine.

Table 3 Microbiological quality of the final wine.

\begin{tabular}{llll}
\hline Sample & Total bacteria count $(\mathrm{cfu} / \mathrm{mL})$ & Total fungal count $(\mathrm{cfu} / \mathrm{mL})$ & Total coliform count $(\mathrm{cfu} / \mathrm{mL})$ \\
\hline Rose red pawpaw wine & $1.0 \times 10^{6}$ & Nil & Nil \\
Yellow pawpaw wine & $1.0 \times 10^{6}$ & Nil & Nil \\
\hline
\end{tabular}


Table 4 Mean sensory scores of the final wine.

\begin{tabular}{llllll}
\hline Samples & Colour & Aroma & Taste & Clarity & Overall acceptability \\
\hline A & $6.40^{\mathrm{b}}$ & $5.95^{\mathrm{b}}$ & $5.20^{\mathrm{b}}$ & $6.75^{\mathrm{a}}$ & $6.08^{\mathrm{a}}$ \\
B & $6.10^{\mathrm{b}}$ & $5.95^{\mathrm{b}}$ & $5.90^{\mathrm{a}}$ & $6.35^{\mathrm{a}}$ & $6.08^{\mathrm{a}}$ \\
C & $8.80^{\mathrm{a}}$ & $8.55^{\mathrm{a}}$ & $8.50^{\mathrm{a}}$ & $8.50^{\mathrm{a}}$ & $8.59^{\mathrm{a}}$ \\
LSD & 2.17 & 2.01 & 2.74 & 2.42 & 2.56 \\
\hline
\end{tabular}

Values in the same column having different superscripts differ significantly at $p<0.05$.

Keys: $\mathrm{A}=$ red paw-paw wine, $\mathrm{B}=$ yellow paw-paw wine, $\mathrm{C}=$ imported grape wine.

$1.0 \times 10^{6} \mathrm{cfu} / \mathrm{mL}$ for both wines. The increase in the total yeast count during aerobic fermentation can be attributed to the presence of utilizable sugar (sucrose) and yeast nutrient. The daily aeration of the fermenting must also has aided rapid multiplication of the yeast cells [39]. Lower microbial count of the wine may specifically be as a result of the presence of alcohol, organic acids and increase in total acidity. Alcohol inhibits bacterial growth by plasmolyzing bacterial cell walls. In addition, low $\mathrm{pH}$ inhibits pathogenic and putrefactive bacterial activity, thus affecting bacterial growth and metabolism [40-43].

Coliform was not detected in the wine samples and the presence of coliforms generally signifies poor sanitary condition. The International Commission on Microbiological Specifications for Foods (ICMSF) [44] recommended absence of coliform in wines. The absence of coliform in the pawpaw wine samples therefore makes it safe for human consumption.

\subsection{Sensory Evaluation of the Final (Pawpaw) Wines}

Table 4 showed the mean sensory scores of yellow and dried pawpaw wine. Colour of the wine samples ranged from 6.40-8.85 with the imported grape wine rated as most preferred and yellow pawpaw wine as least preferred with no significant $(p<0.05)$ difference.

Aroma ranged from 5.95-8.55 with the two varieties of pawpaw wine rated as least preferred in both cases and the imported grape wine as most preferred. Results also showed a significant $(p<0.05)$ difference between the imported grape wine and the pawpaw wines.

Taste of the wine samples ranged from 5.20-8.50 with the imported as most preferred and the red pawpaw wine variety as least preferred. The yellow pawpaw wine variety showed no significant $(p<0.05)$ difference with the imported grape wine. Clarity and overall acceptability of the wine samples ranged from 6.35-8.50 and 6.08-8.59 respectively with the imported grape wine rated as most preferred and yellow pawpaw wine as least preferred in both cases. Results showed no significant $(p>0.05)$ difference in the clarity and overall acceptability of imported grape wine and pawpaw wine varieties.

\section{Conclusion}

The $\mathrm{pH}$ and sugar concentration decreased with increase in the number of days of fermentation. The specific gravity also decreased gradually during fermentation. The titrable acidity increased during fermentation while alcohol content of the yellow pawpaw wine $(8.0 \%)$ was more than the red pawpaw wine $(7.69 \%)$. The alcohol content of the pawpaw wines was comparable with imported grape (7.5\%) wine while sugar content was lower as compared to imported wine. The yellow pawpaw wine was preferred than the red pawpaw wine as it showed high alcohol content and high acidity. Sensory results showed that the yellow pawpaw wine was preferred to the red pawpaw. However, both wines compared favourably with the imported grape while clarity and overall acceptability of the red wine compares well with the control wine sample with no significant $(p>$ $0.05)$ difference from the yellow pawpaw wine. This study has demonstrated that it is possible to produce wines from pawpaw varieties with good microbiological standard and acceptability. 


\section{References}

[1] Reddy, L. V., and Reddy, O. V. S. 2005. "Production and Characterization of Wine from Mango Fruit (Mangifera indica)." World Journal of Microbiology and Biotechnology 21: 1345-50.

[2] Rivera-Espinoza, Y., Valdez-López, E., and Hernández-Sánchez, H. 2005. "Characterization of a Wine-Like Beverage Obtained from Sugarcane Juice." World Journal of Microbiology and Biotechnology 21: 447.

[3] Kimball, D. 1991. Citrus Processing: Quality Control and Technology. New York: Van Nostrand Reinhold, p. 2.

[4] Akingbala, J. O., Oguntimein, G. B., Olunlade, B. A., and Aina, J. O. 1992. "Effects of Pasteurization and Packaging on Properties of Wine from Over-Ripe Mango (Mangifera indica) and Banana (Musa acuminata) Juices." Tropical Science 34: 345-52.

[5] Sandhu, D. K., and Joshi, V. K. 1994. "Comparative Fermentation Behaviour and Chemical Characteristics of Saccharomyces and Zymomonas Fermented Culled Apple Juice." Indian Journal of Experimental Biology 32 (2): 873-6.

[6] Joshi, V. K., Sandhu, D. K., and Thakur, N. S. 2000. "Fruit Based Alcoholic Beverages." In Biotechnology: Food Fermentation, edited by V. K. Joshi and A. Pandey, Vol. II, pp. 647-732.

[7] Ohoke, F. O., and Igwebike, O. C. D. 2017. "Physico-chemical Properties and Sensory Evaluation of Wine Produced from Tiger Nut (Cyperus esculentus)." International Journal of Chem Tech Research 10 (12): 155-64.

[8] Jackson, R. S. 2000. Wine Science: Principles, Practice, Perception. 2nd ed. San Diego, California: Academia Press.

[9] Peynaud, E. 1987. Knowing and Making Wine. USA: John Wiley \& Sons, p. 391.

[10] Shrikant, B. S., Thakor, N. J., and Divate, A. D. 2014. "Fruit Wine Production: A Review." Journal of Food Research and Technology 2 (3): 93-100.

[11] Kochhar, S. L. 1987. "Pawpaw Fruit." In Tropical Crops: A Textbook of Economic Botany, edited by Kochhar, S. L. New Delhi, India: Macmillan Company Publishers, pp. 263-4.

[12] Rice, R. P., Rice, L. W., and Tindall, H. D. 1987. "Pawpaw." In Fruits and Vegetable Production in Africa, edited by R. P. Rice, London: Macmillan Publishers Ltd., p. 170.

[13] Sofoware, A. 1997. Medicinal Plants Used in Traditional Medicine in Africa. 1st ed., New York: John Wiley and Sons, pp. 128-9.
[14] Jaime, A., da Teixeira, S., Zinia, R., Manoel, T. S., and Paula, F. T. 2007. "Papaya (Carica papaya L.) Biology and Biotechnology." Tree and Forestry Science and Biotechnology 1: 47-73.

[15] Zhou, K., Wang, H., Mei, W., Li, X., Luo, Y., and Dai, H. 2011. "Antioxidant Activity of Papaya and Extracts." $\begin{array}{llll}\text { Molecules } & 16 & \text { (8): } & \text { 6176-92. }\end{array}$ doi:10.3390/molecules16086179.

[16] Maisarah, A. M., Asmah, R., and Fauziah, O. 2014. "Proximate Analysis, Antioxidant and Anti Proliferative Activities of Different Parts of Carcia papaya." Journal of Nutrition and Food Science 4 (2): 267-72. doi:10.4172/2155-9600.1000267.

[17] Devitt, L. C., Fanning, K., Dietzgen, R. G., and Holton, T. A. 2010. "Isolation and Functional Characterization of a Lycopene Beta-Cyclase Gene That Controls Fruit Colour of Papaya (Carica papaya L.)." J Exp Bot. 61: 33-9.

[18] Zaman, W., Biswas, S. K., Helali, M. O. H., Ibrahim, M., and Parvez, H. 2006. "Physicochemical Composition of Four Papaya Varieties Grown at Rajshahi." J. Bio-Sci. 14: 83-6.

[19] Okoro, C. E. 2007. "Production of Red Wine from Roselle (Hibiscus sabdariffa) and Pawpaw (Carica papaya) Using Palm-Wine Yeast (S. cerevisiae)." Nigerian Food Journal 25 (2): 158-64.

[20] Amerine, M. A., and Kunkee, R. E. 2002. "Microbiology of Wine Making." Ann. Rev. Microbiol. 2: 232-58.

[21] Robinson, J. 2006. The Oxford Companion to Wine. New York: Oxford University Press.

[22] AOAC. 2012. Association of Official Analytical Chemists Official Methods of Analysis. 19th ed., Washington, DC USA.

[23] Ogu, E. O., and Mgbebu, P. O. 2011. Foundation for African Development through International Biotechnology (FADIB). 19: 49-53.

[24] Iwe, M. O. 2002. Handbook of Sensory Methods and Analysis. Enugu, Nigeria: Rojoint Communications Services Limited, p. 14.

[25] Harrigan, W. F. 1998. Laboratory Methods in Microbiology. Califonia, USA: Academics Press.

[26] Cheesbrough, M. 2002. "Water-Related Diseases and Testing of Water Diseases." In District Laboratory Practice in Tropical Countries. Cambridge: Cambridge University Press, pp. 143-57.

[27] Okeke, B. C., Agu, K. C., Uba, P. O., Awah, N. S., Anaukwu, C. G., Archibong, E. J., Uwanta, L. I., Ezeneche, J. N., Ezenwa, C. U., and Orji, M. U. 2015. "Wine Production from Mixed Fruits (Pineapple and Watermelon) Using High Alcohol Tolerant Yeast Isolated from Palm Wine." Universal Journal of Microbiology Research 3 (4): 41-5.

[28] Ogodo, A. C., Ugbogu, O. C., Ugbogu, A. E., and Ezeonu, 
C. S. 2015. "Production of Mixed Fruit (Pawpaw, Banana and Watermelon) Wine Using Saccharomyces cerevisiae Isolated from Palm Wine." Springer Plus 4: 683-9.

[29] Obaedo, M. E., and Ikenebomeh, M. J. 2009. "Microbiology and Production of Banana (Musa sapientum) Wine." Nigerian Journal of Microbiology 23: 1886-91.

[30] Sahu, U. C., Panda, S. K., Mohapatra, U. B., and Ray, R. C. 2012. "Preparation and Evaluation of Wine from Tendu (Diospyros melanoxylon L.) Fruits with Antioxidants." International Journal of Food and Fermentation Technology 2 (2): 167-78.

[31] Ray, R. C., Panda, S. K., Swain, M. R., and Sivakumar, S. P. 2012. "Proximate Composition and Sensory Evaluation of Anthocyanin-Rich Purple Sweet Potato (Ipomoea batatas L.) Wine." International Journal of Food Science and Technology 47 (3): 452-8. doi:10.1111/j.1365-2621.2011.02861.x.

[32] Ayogu, T. E. 1999. "Evaluation of the Performance of Yeast Isolate from Nigerian Palm Wine in Wine Production from Pineapple Fruits." Bioresource Technology 69: 189-90.

[33] Okunowo, W. O., Okotore, R. O., and Osuntoki, A. A. 2005. "The Alcoholic Fermentation Efficiency of Indigenous Yeast Strains of Different Origin on Orange Juice.” African Journal of Biotechnology 4 (11): 1290-6.

[34] Clement-Jimenez, J. M., Mingorance-Cazorla, L., Martinez-Rodoriguez, S., Las Heras, V. F. J., Rodriguez-Vico, F. 2005. "Influence of Sequential Yeast Mixtures on Wine Fermentation." International Journal of Food Microbiology 98: 301-8.

[35] Reddy, L., Reddy, V. A., Reddy, O., and Joshi, V. K. 2014. "Production of Wine from Mango Fruit: A Review." International Journal of Food and Fermentation Technology 4: 13-25.

[36] Michael, P. 2000. "Foods of the Gods: Part 1-Wine in Ancient Egypt." Accessed July 16, 2018. www.touregypt.net/egypt-info/magazine-mag11012000magf $2 . h t m$.

[37] Jack, B. K. 2007. "Wine Making." http://www.Jack.keller.net.

[38] Selvaraj, Y., Subramanyam, M. D., and Iyer, C. P. A. 1982. "Changes in the Chemical Composition of Four Cultivars of Papaya (Carica papaya L.) during Growth and Development." J. Hort. Sci. 57: 135-43.

[39] Berry, C. J. J. 2000. First Steps in Wine Making. G. W. Kent Inc.

[40] Mountney, G. J., and Gould, W. A. 1988. Practical Food Microbiology and Technology. New York, USA: Van Nostrand Reinhold Company.

[41] Frazier, W. C., and Westhoff, D. C. 1991. Food Microbiology. 3rd ed., New Delhi: Tata McGram Hill.

[42] Adams, M. R., and Moss, M. O. 1995. Food Microbiology. Cambridge, UK: The Royal Society of Chemistry.

[43] Garbutt, J. 1997. Essentials of Food Microbiology. Arnold Publishers, pp. 103-245.

[44] ICMSF. 1996. "Toxigenic Fungi: Aspergillus." In Microorganisms in Foods 5: Characteristics of Food Pathogens. London: Academic Press, pp. 347-81. 